\title{
Role and Frequency of Asthma Risk Factors in Triggering the Asthmatic Attack: A Cross-Sectional Study from Pakistan
}

\author{
Gillani Ali Hassan ${ }^{1 *}$, Shaker Ahsan², Mustafa Asem², Iqbal Taha'2, Usman Muhammad², Malik \\ Waqar Saleem ${ }^{3}$, Ahmed Abu Bakar², Mingwei Chen ${ }^{3}$ \\ ${ }^{1}$ Department of Pharmacy Administration and Clinical Pharmacy, School of Pharmacy, Xi'an Jiaotong University, \\ Shaanxi, CHINA \\ ${ }^{2}$ Department of Pharmacy, Islamia University of Bahawalpur, Punjab, PAKISTAN. \\ ${ }^{3}$ Department of Pulmonology, Xi'an Jiaotong University, Shaanxi, CHINA
}

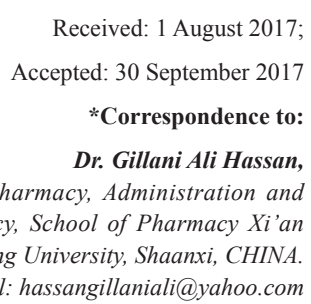

Email: hassangillaniali@yahoo.com

Copyright: $(\subset$ the author(s),publisher and licensee Indian Academy of Pharmacists. This is an openaccess article distributed under the terms of the Creative Commons Attribution Non-Commercial License, which permits unrestricted non-commercial use, distribution, and reproduction in any medium, provided the original work is properly cited.

\begin{abstract}
Background: There is a growing interest in the attempts, made to understand what the asthma risk factors are and their frequency in triggering asthma attacks. Methods: Retrospective study was conducted. Community and hospital based cross-sectional study was performed between February 2015 and June 2015 in Bahawalpur region. 341 patients were approached using systemic sampling technique while only 209 patients were willing to participate in the study. Survey questionnaire consisted of three parts including, demographic information, triggering risk factors, and use of precautionary measures. Summarization of data was accomplished by descriptive statistics. Complete analysis was done using SPSS version 16.0. Results: Out of 209, $109(52.1 \%)$ were males and $100(47.9 \%)$ were females with the overall average mean age \pm SD of $22.29 \pm 13.49$ years. Dust factor being the leading cause that triggers the asthmatic attack in $93.3 \%$ (195) patients followed by pollution $80.3 \%$ (168), seasonal factors $64.6 \%$ (135), smoking $49.7 \%$ (104), cold air 34\% (71), occupational chemicals $18.6 \%$ (39), pet animals $16.3 \%$ (34), stress $9.5 \%(20)$, cockroaches $8.1 \%(17)$ and the least affecting factor was medicine use affecting $2.9 \%$ (6). Furthermore only $46(22 \%)$ patients used precautionary measures and confirmed its effectiveness in preventing the asthmatic attack when they were exposed to the risk factors. Out of 192 who were prescribed with the inhaler only $59.3 \%$ patient can use inhaler effectively and $88.5 \%$ keep it with them while traveling to prevent the worsening of asthmatic attack. Conclusion: Asthma is not a lethal disease but can prove fatal by slackness. Evasion of risk factor is the prime act in asthma care. The use of the precautionary measures was proved to be of immense significance in preventing asthma. The use of inhalers was also prescribed but many patients were unable to use them appropriately leading to their therapeutic failure.

Key words: Asthma, Risk factor, Triggering factors, Pakistan.
\end{abstract}

\section{INTRODUCTION}

Asthma is the inflammatory disease occurred due to the hyper responsiveness of the immune system which ultimately results in the pro-inflammatory mediator release and airways obstruction. ${ }^{[1]}$ This hypersensitivity is triggered by the allergen exposures, air pollution, cigarette smoking and noxious particle insult. ${ }^{[2]}$ In children, the most common triggers are viral illnesses such as those that cause 
the common cold. ${ }^{[3]}$ Between episodes, most patients feel well but can have mild symptoms and they may remain short of breath after exercise for longer periods of time than the unaffected individual. ${ }^{[4]}$

Asthma enhances the burden on the health care system in various countries of the world but morbidity and mortality of asthma can be reduced by standard care practices. ${ }^{[5]}$ Public attention in the developed world has recently focused on asthma because of its rapidly increasing prevalence, affecting up to one in four urban children. ${ }^{[6]}$ Asthma is a prevalent chronic illness in the United States that has been increasing in prevalence since $1980 .{ }^{[7]}$ The asthma prevalence ranges in adults from $2.7 \%-4.0 \%, 7.1 \%-12 \%, 9.1 \%-17.9 \%$ in England, USA and Australia respectively. Genetic cause of asthma was strongly supported by the example of Tristan da Cunha which has the prevalence of $51 \%{ }^{[8]}$

Pakistan is among the countries with most frequent cases of hospitalization with asthma and prevalence of asthma in children is $20 \%{ }^{[9]}$ and affecting almost $1 / 4^{\text {th }}$ patients in the health care facilities. From 1997 to 2006 prevalence among 12-13 years old escalated from $10 \%$ to $18 \%$ in Pakistan ${ }^{[10]}$ and the chances of reduced mental health and developmental problems were observed with asthma. ${ }^{[1]}$ During 1991-2001, the problem of asthma had been the focus of programs and reports from governmental agencies e.g., the National Heart Lung and Blood Institute's National Asthma Education and Prevention Program $[\text { NAEPP }]^{[12]}$ and the U.S. Department of Health and Human Services' Action Against Asthma report ${ }^{[13]}$ and nongovernmental commissions (e.g., the Pew Environmental Health Commission's Attack Asthma report). ${ }^{[14]}$ A common feature of these reports and programs was a call for improved asthma surveillance. ${ }^{[15]}$ In 2009 asthma caused 250,000 deaths globally. ${ }^{[16]}$ Despite this, proper control of asthma with step down therapy, prognosis is generally $\operatorname{good}^{[17]}$

The objective of this study was to present the most common and least common factors trigger asthmatic attack in Bahawalpur. There was no study available of this type in the past literature so this study will be helpful to understand the effect of different risk factors on the patients.

\section{MATERIALS AND METHOD}

Study design: A descriptive cross-sectional study design was adopted among the patients of asthma in the
Bahawalpur city, Punjab, Pakistan during May 2014 to July 2014. Study site: Bahawalpur, located in the cholis tan region, a divisional headquarter of Punjab Pakistan at an altitude of $29^{\circ} 39^{\prime} 61^{\prime \prime}$ north and $71^{\circ}$ 69'79" east. Population of Bahawalpur was 7.51 million according to national consensus data taken way back in 1998. According to this data Bahawalpur had 10\% of the total population of the Punjab province which itself is the largest province of Pakistan. Majority of population is living in the rural and semi-rural areas. [18] Study instrument: A questionnaire was being developed, containing different risk factors of asthma. The Performa consisted of four parts. The first part contained the demographic variables of the patient (e.g. age, sex, occupational status, family income). The $2^{\text {nd }}$ part consists of the sign and symptoms to classify the patients. Asthmatic patients were distinguished from other patients on the manifestation of the symptoms and classified as acute or chronic asthmatics. 3rd part consisted of the closed ended questions about the risk factors (dust, mites, pollen grains, smoke, medicine, emotional stress, seasonal, pets, insects, cold air) of asthma. The patients were asked if they face the asthmatic attack on the exposure to these risk factors. The patient was asked to answer in yes or no e.g Do you face asthmatic attack when exposed to dust, yes was the answer if he was affected by the dust and No if not affected. The risk factor was counted if the answer of the patient was positive. The fourth part consisted of the question that either patient was taking the precautionary measure (e.g. Do you use mask whenever go out of home?) and to know the how many patients were prescribed with inhaler and how many of them can use it properly. The proper use of inhaler was assessed by the demonstration of the patient on use of inhaler.

Questionnaire validation: The questionnaire was validated prior to start of study using the same data collection technique, we were planning to adopt during the data collection. A pilot study was done on the 20 patients and suitable changes were made in the questionnaire. The respondents of the pilot study were not included in the study. Data collection and statistical analysis: Pakistan health system comprises of the both public and private sector. There are 10,000 public health care facilities in Pakistan. The private sector comprised of private hospitals, private clinics and pharmacies which provide health care to $70 \%$ of the Pakistan population. ${ }^{[19]}$ A prospective study was done between February 2015 to July 2015 by visiting different patients of asthma in the chest ward of the Baha Wal Victoria Hospital (BVH) 
Bahawalpur and the private clinics of the doctors in the city of Bahawalpur. Systemic sampling technique was adopted in each setting. The patient was included if he showed the sign of sneezing or whistling sound from chest in the morning or suffered from asthma or have asthmatic attack in the last 12 months. ${ }^{[20]}$

Acute and chronic asthma patients were included. Face to face interview with the patient was conducted. To acquire the data from the children or patients which cannot cope with the interviewer, interview was taken from the close relatives. Verbal or written consent was taken before the commencement of the interview. Data was summarized by descriptive statistics and chi square test was used to estimate the significance among the variables. The complete analysis was done by the SPSS version 16.0.

\section{RESULTS}

Total 341 patients were approached using systemic random sampling method (190 from private setting 151 from the hospital). Out of these 341 patients, 209 (135 from private clinics and 74 from Chest ward) were agreed to take part in the study. The response rate was $61.3 \%$. The mean \pm S.D age $22.29 \pm 13.40$. Out of total $109(52.2 \%)$ were males while most of them were younger than 18 years $(59.3 \%)$. The income status of the patients showed that it was most common in high income families $(35.9 \%$ patients with family income higher than 50000). Most of the population was resident of the urban areas $(72.2 \%)$ Table 1.

\section{Risk Factors}

The leading risk factor which affects most of the patients was dust, which triggers the asthmatic attack in the 195 (93.3\%). Patients of Different age groups, residence income status and gender were insignificantly affected by this risk factor. The $2^{\text {nd }}$ most teasing factors for asthmatic patient was pollution which affected $168(80.3 \%)$ patient. The effect of this risk in urban and rural patient was insignificant while all other demographic characters were significantly affected. 135 (64.6\%) patients complained the worsening of their asthma in pollen season. This risk factor affected the gender significantly while all other characteristics were insignificantly associated. Smoking (direct or indirect) triggered the asthmatic attack in the 104 (49.7\%) patients. It significantly affected the population of different gender.

$71(34 \%)$ patients confirmed that when they were exposed to cold air their asthma got worse. Ratio of

\begin{tabular}{|c|c|c|}
\hline \multicolumn{3}{|c|}{ Age $(22.29 \pm 13.49)$} \\
\hline$\leq 18$ & 124 & 59.3 \\
\hline $19-25$ & 14 & 6.7 \\
\hline $26-40$ & 43 & 20.6 \\
\hline$>40$ & 28 & 13.4 \\
\hline \multicolumn{3}{|l|}{ Gender } \\
\hline Male & 109 & 52.2 \\
\hline Female & 100 & 47.8 \\
\hline \multicolumn{3}{|l|}{ Locality } \\
\hline Urban & 151 & 72.2 \\
\hline Rural & 58 & 28.8 \\
\hline \multicolumn{3}{|l|}{ Family Income } \\
\hline$\leq 15000$ & 13 & 6.2 \\
\hline $16000-30000$ & 63 & 30.1 \\
\hline 31000-50000 & 58 & 27.8 \\
\hline$>50000$ & 75 & 35.9 \\
\hline \multicolumn{3}{|l|}{ Interview place } \\
\hline Govt Hospital & 135 & 64.5 \\
\hline Private clinic & 74 & 35.5 \\
\hline
\end{tabular}

males was high as compared to females $(70.4 \%$ males, $29.6 \%$ Females). Gender and age was significantly strained by cold air. Some occupations were affecting the human respiratory system for examples the persons working on the gas stations or petrol stations, working in the workshops, welding shops or in industry were at continuous exposure to harmful chemicals. 39 (18.6\%) patients confirmed that whenever they got exposure to some unusual chemicals they got asthmatic attack. There was significant association of occupational factor and triggering of asthma attack in males and females.

$\begin{array}{ll}\begin{array}{l}\text { Table 2: Number of Patients affected by Different risk } \\ \text { factors. }\end{array} \\ \begin{array}{l}\text { Risk factor } \\ \text { Number of patients affected N } \\ \text { (\%) }\end{array} \\ \text { Dust } & 195(93.3 \%) \\ \text { Pollution } & 168(80.3) \\ \text { Seasonal } & 135(64.6) \\ \text { Smoking } & 104(49.7) \\ \text { Cold air } & 71(34) \\ \text { Occupational } & 39(18.6) \\ \text { Pet animals } & 34(16.3) \\ \text { Stress } & 20(9.5) \\ \text { Cockroaches } & 17(8.1) \\ \text { Medicines } & 6(2.8)\end{array}$


$34(16.3 \%)$ had allergy to pet animals $(55.9 \%$ males and $44.1 \%$ females). No significant influence of this risk factor was observed with demographic characters. 20 $(9.5 \%)$ patients said whenever they were stressed they had worsening of their asthma (60\% males and $40 \%$ females). It had influential effect in triggering asthma attack in the urban and rural population. Another interesting risk factor which has relation with the triggering of asthmatic attack were cockroaches which affects total $17(8.1 \%)$ patients, females were more affected $12(70.5 \%)$ then males (29.5\%). Medicine like aspirins and some others are also harmful for the asthma patient. 6 patients $(2.9 \%)$ were affected by medicines (66.7\% males, $33.3 \%$ females). No significant association was found between cockroaches and medicine on any of demographic character Table 2.

Use of Precautionary measure

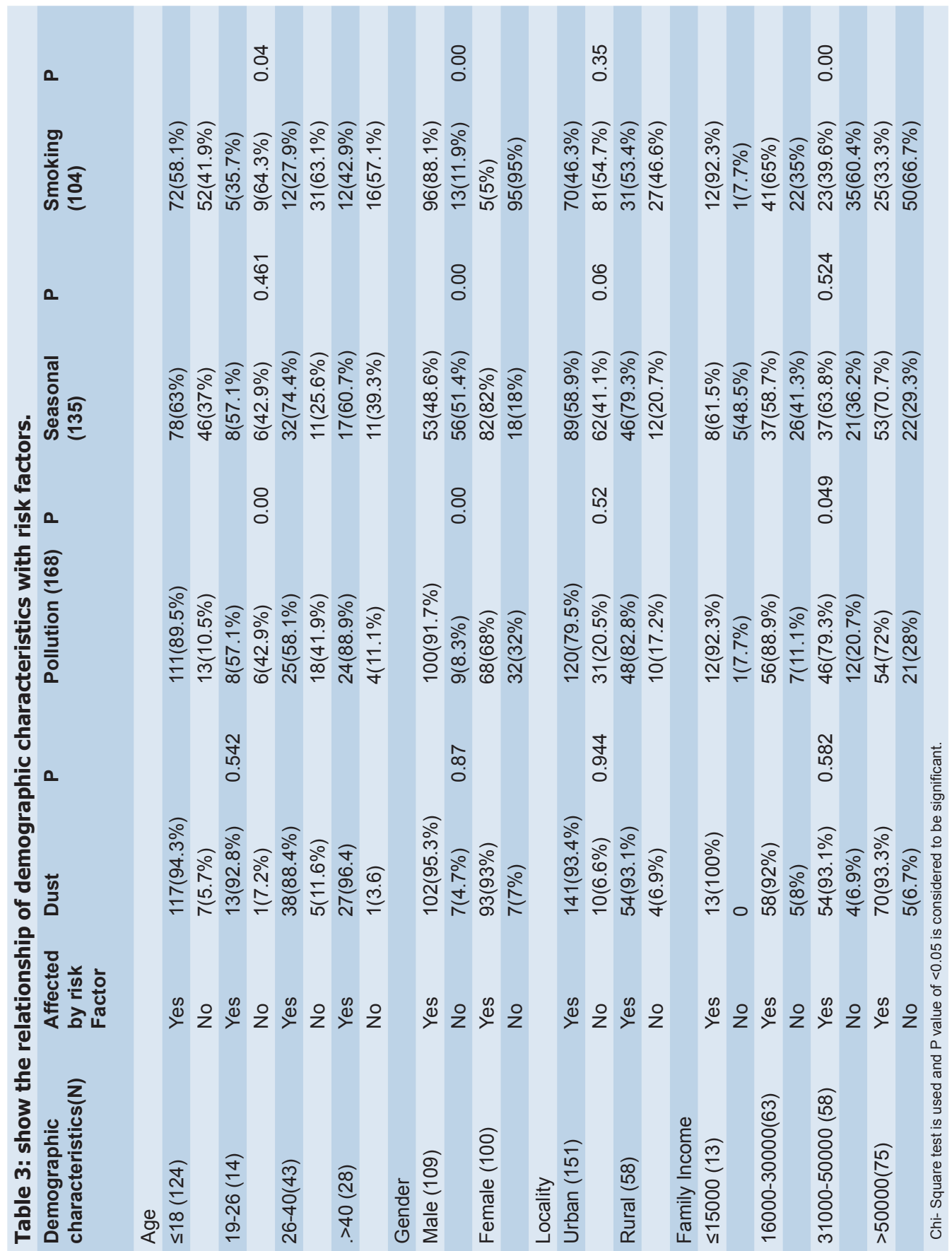




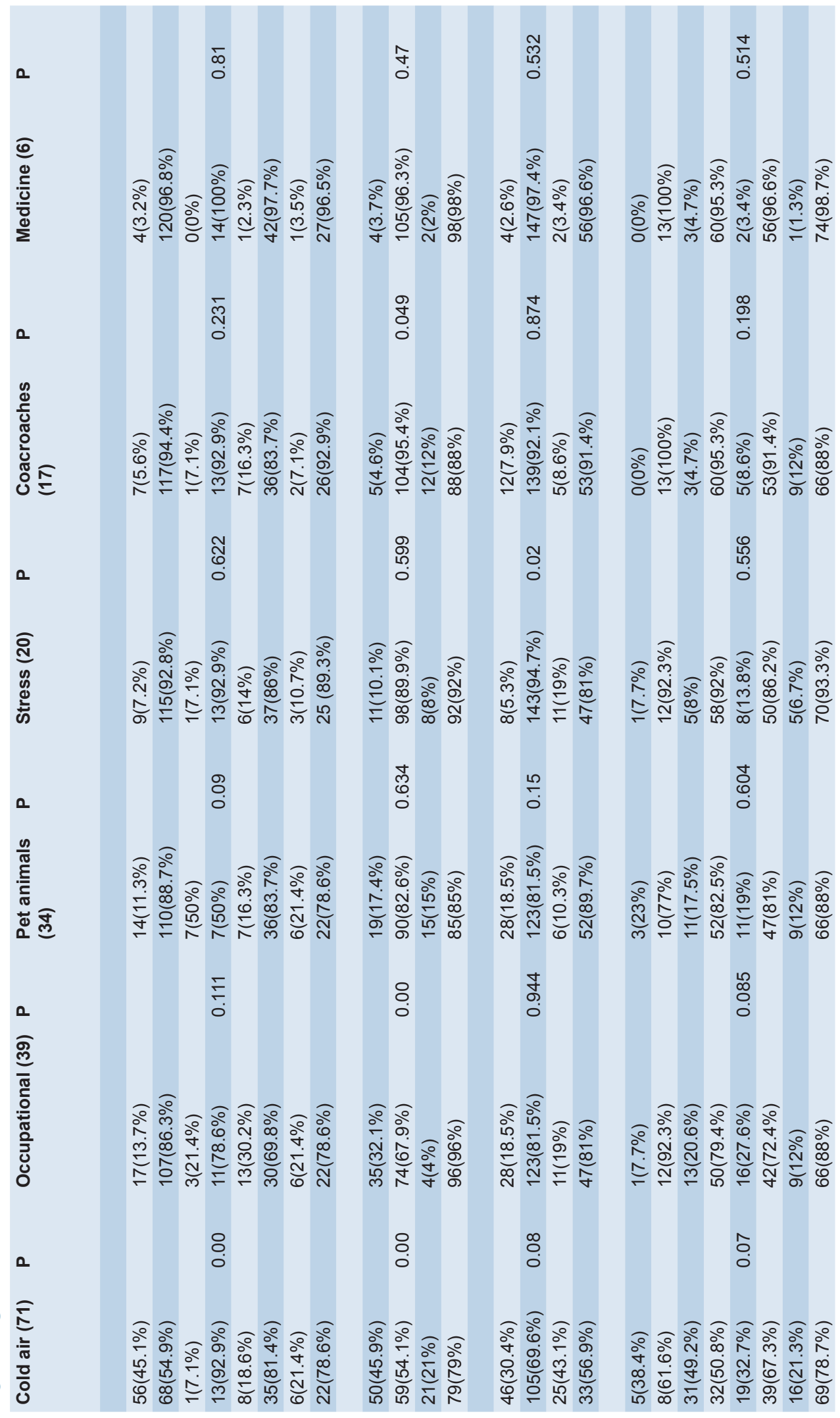




\begin{tabular}{|c|c|c|c|c|}
\hline Demographics & $\begin{array}{l}\text { Use } \\
\text { mask N } \\
(\%)\end{array}$ & $\begin{array}{l}\text { Asymp. } \\
\text { sig* }^{*}\end{array}$ & $\begin{array}{l}\text { Inhaler } \\
\text { use } \mathbf{N} \\
(\%)\end{array}$ & $\begin{array}{l}\text { Asymp. } \\
\text { sig* }^{*}\end{array}$ \\
\hline \multicolumn{5}{|l|}{ Gender } \\
\hline Male & $\begin{array}{l}21 \\
(45.6)\end{array}$ & & $\begin{array}{l}55 \\
(48.2)\end{array}$ & \\
\hline Female & $\begin{array}{l}25 \\
(54.4)\end{array}$ & 0.318 & $\begin{array}{l}59 \\
(51.8)\end{array}$ & 0.215 \\
\hline \multicolumn{5}{|l|}{ Age group } \\
\hline$\leq 18$ & $\begin{array}{l}21 \\
(45.6)\end{array}$ & & $\begin{array}{l}63 \\
(55.3)\end{array}$ & \\
\hline $19-25$ & $3(6.5)$ & & $7(6.1)$ & \\
\hline $26-40$ & $\begin{array}{l}15 \\
(32.6)\end{array}$ & & $\begin{array}{l}25 \\
(21.9)\end{array}$ & \\
\hline$>40$ & $7(15.2)$ & $0.120 a$ & $\begin{array}{l}19 \\
(16.7)\end{array}$ & $0.377 a$ \\
\hline \multicolumn{5}{|l|}{ Locality } \\
\hline Urban & $\begin{array}{l}28 \\
(68.9)\end{array}$ & & $\begin{array}{l}84 \\
(73.7)\end{array}$ & 0.612 \\
\hline Rural & $\begin{array}{l}18 \\
(31.1)\end{array}$ & 0.051 & $\begin{array}{l}30 \\
(26.3)\end{array}$ & \\
\hline \multicolumn{5}{|c|}{$\begin{array}{l}{ }^{*} \text { Chi- Square test is used and value of }<0.05 \text { is considered to be significant. a is the } \\
\text { likelihood ratio because one cell has minimum expected value less than } 5\end{array}$} \\
\hline \multicolumn{5}{|c|}{$\begin{array}{l}\text { Table 5: Prevalence of Asthma with different age } \\
\text { groups. }\end{array}$} \\
\hline Age Groups & \multicolumn{2}{|c|}{ Males } & \multicolumn{2}{|c|}{ Females } \\
\hline$\leq 15$ & \multicolumn{2}{|c|}{51} & \multicolumn{2}{|l|}{46} \\
\hline $16-25$ & \multicolumn{2}{|c|}{19} & \multicolumn{2}{|l|}{9} \\
\hline $26-40$ & \multicolumn{2}{|c|}{14} & \multicolumn{2}{|l|}{28} \\
\hline$\geq 41$ & \multicolumn{2}{|c|}{14} & \multicolumn{2}{|l|}{28} \\
\hline
\end{tabular}

Use of precautionary measure is useful weapon against the asthma. The major precautionary measure we focused on was use of mask to avoid the risk factor from entering the respiratory system. $46(22 \%)$ patients strictly obey the rule "Precaution is better than cure" and wear mask whenever they go out of houses. Different age groups vary in their use to the precautionary measures. The patients with Age $\leq 18$ (45.5\% Use mask) were much more prone to take precautionary measures while patients in the age between19-25 (6.5\%) were most reckless in taking precautions against asthma. Males and females were almost equally attentive toward precautionary measures. Urban population was much cautious about the disease and use mask more frequently then rural population (68.9\% Urban $31.1 \%$ rural).

\section{Use of Inhaler}

The inhalation route of administration was proved to be well effective in the treatment of asthma. Its effectiveness can be judged by the results that 192 patients were prescribed with the Inhaler but only $59.35 \%$ patients can use it effectively while others complain of difficulty in its use. There was no significant difference in the different age groups, residential status and gender on the proper use of the Inhaler.

\section{DISCUSSION}

The asthma is an allergy, caused by number of allergens. All allergens affect the respiratory tract by different mechanism and stimulate the human immune response to tackle these allergens, result in either narrowing of the respiratory tract or excess secretion of the mucus. However, our study enabled us to demonstrate, for the first time in Pakistan the most common and the least common risk factors which play their role in triggering the allergic attack. Furthermore, the study demonstrated the effect of gender, locality and age on the use of precautionary measures and proper use of inhaler.

Asthma prevalence varies with age. The asthma is more common in boys than girls in childhood while the ratio of male and female is same around the age of 20 years and it is more common in females then males above the age of $40 .{ }^{[21]}$ The results of this study were somewhat like the fact. $22 \%$ Females younger than the 15 years have asthma whereas the percentage of males was $24.4 \%$ whereas females are more affected by asthma in the older age $40+$.

Research evidences indicated the link between some forms of asthma and degree of affluence of society concerned. This could possibly be due to the 'Hygiene factor', whereby lack of childhood exposure to some ecological irritants increases the sensitivity of susceptible people to develop asthma on later exposure. [22] The results of our study coincide with this hypothesis as $35.9 \%$ of our study population had high economic status. The urban and rural population was not equally effected by asthma. Urban areas were expected to have more cases then rural. ${ }^{[23,24]}$ The difference between the rural and urban population lies in the fact that urban population are closer to the Risk factors of asthma then rural population. ${ }^{[25]}$ Our study population was mainly from urban area $(72.2 \%)$.

There is the evidence from the previous studies that risk factors of this study are related to development of asthma and triggering the attack by different 
mechanisms. Pollution produces continuous irritation and increase mucus secretion. There was a positive relationship between the pollution and asthmatic attack $^{[26]}$ Stress modulates the immune system and indirectly increases the chances of asthma. ${ }^{[27]}$ Smoking destroys the cilia and let the mucus to accumulate. Smoking directly or indirectly affects the respiratory system and lead to development of asthma. Maternal smoking adversely affects the child. ${ }^{[28]}$ Some medicines also play role in the development and triggering the attack e.g Metoprolol, aspirin. ${ }^{[18]}$ The indoor factor is the exposure to the volatile organic compounds. The mechanism of action of volatile organic compounds exposure may be allergic sensitization mediated by a $\mathrm{Th}_{2}$ cell phenotype. ${ }^{[2]}$ Another indoor factor was the use of phthalates in building materials e.g. DEHP (di-ethylhexyl phthalate which is a plasticizer). ${ }^{[30]}$ The hydrolysis product of DEHP is MEHP which mimics the prostaglandins and thromboxane's in the airway leading to symptoms related to asthma. ${ }^{[31]}$ The dust particles were strongly related with the development and worsening of asthmatic attack. Dust increases the burden for hospitalization in children. ${ }^{[32]}$ The presence of animals in the home was not appeared to be a major risk factor for asthma in this study, perhaps because domestic animals were less confined to the house showed animal or pet exposure as $18.28 \% .{ }^{[33]}$

Allergen avoidance is the best strategy to deal with allergic disorders. Asthma prevention lies in the avoiding of risk factors. Using the precautionary measure to avoid the allergen proved to be of the great importance in the fight against asthma. Age had a great influence in the use of mask for the different conditions. ${ }^{[34]}$

According to finding of our study the patients with age lower than 18 were more prone to use mask while going away from home. The reason behind this result might be the influence of the parents or care givers to adopt the habit of wearing mask. Where ever family care is a tool for the prevention and management against the asthma. ${ }^{[35]}$ Females have habit of wearing the mask in any conditions more than men. ${ }^{[34]}$ Our study revealed the same results. Our study showed urban population use more face masks as compared to rural population where as these results contras indicated the study conducted back in Taiwan. ${ }^{[36]}$

Inhalation route of administration was proven to be most effective route of administration in the prevention and management of the Asthma. ${ }^{[37,38]}$
Proper and effective use of the inhaler provide the therapeutic outcomes where improper use will lead to the therapeutic failure and poor asthma control ${ }^{[37]}$ this study illustrates that there was the significant difference between the gender, age and rural and urban population in the proper use of inhaler whereas the previous studies proved that males can use inhalers more properly then females and no significant difference was observed in the age for the proper use of inhaler. ${ }^{[38]}$

\section{CONCLUSION}

Asthma is not a disease that cannot be handled and manage but it can also prove fatal by negligence. In asthma care avoidance of risk factors holds primary importance. The use of the precautionary measures to prevent the exposure to risk factors is proved to be of great importance in preventing asthma and reducing their attacks. The use of inhalers was also prescribed but many patients were unable to use them correctly leading to their therapeutic failure.

\section{ACKNOWLEDGMENT}

None

\section{SOURCES OF SUPPORT}

None

\section{CONFLICT OF INTEREST}

No conflicts of interest.

\section{REFRENCES}

1. Ahmed A, Tanveer M, Khan GM, Hanif K. Prescribing and Utilization Trends of Anti-Asthmatic Drugs amongst Children in a Tertiary Care Hospital in Lahore, Pakistan. J Pharm Practical Community Med. 2017;3(2):70-5.

2. Koenig JQ. Air pollution and Asthma. J Allergy Clinical Immunology. 1999;104(4):717-22.

3. Lilly CM. Diversity of asthma: evolving concepts of pathophysiology and lessons from genetics. J Allergy Clinical Immunol. 2005;115(4):S526-S31.

4. Pereira MC. Physical training for asthma. Sao Paulo Med J. 2013;132(3):1934.

5. Aqeel T, Akbar N, Dhingra S, Haq NU. Assessment of Knowledge and Awareness Regarding Asthma among School Teachers in urban area of Quetta, Pakistan. J Pharm Practice Community Med. 2015;1(1):18-23.

6. Lilly CM. Diversity of asthma: evolving concepts of pathophysiology and lessons from genetics. J Allergy Clinical Immunol. 2005;115(4):S526-S31.

7. Mannino DM, Homa DM, Pertowski CA, Ashizawa A, Nixon LL, Johnson CA et al. Surveillance for asthma-United States, 1960-1995. MMWR CDC Surveill Summ. 1998;47(1):1-27.

8. Masoli M, Fabian D, Holt S, Beasley R. Global Initiative for Asthma (GINA) program: the global burden of asthma: executive summary of the GINA 
Dissemination Committee report. Allergy. 2004;59(5):469-78.

9. Shahzad K, Akhtar S, Mahmud S. Prevalence and determinants of asthma in adult male leather tannery workers in Karachi, Pakistan: a cross sectional study. BMC Public Health. 2006;6(1):1.

10. Arif AA, Korgaonkar P. The association of childhood asthma with mental health and developmental co-morbidities in low-income families. Journal of Asthma. 2016;53(3):277-81.

11. National Institutes of Health, National Asthma Education Program. Expert panel report 2: guidelines for the diagnosis and management of asthma. Available at www.nhlbi.nih.gov/guidelines/asthma/asthgdln.htm

12. US Department of Health and Human Services. Action against asthma: a strategic plan for the Department of Health and Human Services, 2000. Available at http://aspe.hhs.gov/sp/asthma.

13. The Pew Environmental Health Commission. Attack asthma: why America needs a public health defense system to battle environmental threats. Baltimore, MD: John Hopkins School of Public Health, Pew Environmental Health Commission, 2001. Available at http://pewenvirohealth.jhsph.edu/ $\mathrm{html} /$ home/home.html.

14. Global Initiative for Asthma. National Institute of Health. National Heart, Lung and Blood Institute Publication No. 02-3659.

15. Tippets B, Guilbert TW. Managing Asthma in Children: Part 1: Making the Diagnosis, Assessing Severity". Consultant for Pediatricians 2009;8(5).

16. Ramakrishna P, Ramaiah M. KP Current Clinical Status of Vascular Complications in Diabetes Mellitus Patients and Evaluation of Risk Factors. J Pharm Practice Community Med. 2017;3(3):120-5.

17. Haq NU, Hassali MA, Shafie AA, Saleem F, Farooqui M, Aljadhey. A cross sectional assessment of knowledge, attitude and practice towards Hepatitis B among healthy population of Quetta, Pakistan. BMC Public Health. 2012;12(1):692.

18. Kolarik B, Naydenov K, Larsson M, Bornehag CG, Sundell J. The Association between Phthalates in Dust and Allergic Diseases among Bulgarian Children. Environ Health Perspectives. 2008;116(1):98-103.

19. Asthma Risk Factors, Available from: http://www.webmd.com/asthma/guide/ asthma-risk-factors

20. Von Hertzen LC, Haahtela T. Asthma and atopy - the price of affluence? Allergy. 2004;59(2):124-37.

21. Timm S, Frydenberg M, Janson C, Campbell B, Forsberg B, Gislason T, et al. The Urban-Rural Gradient in Asthma: A Population-Based Study in Northern Europe. Inter J Environ Res Public Health. 2015;13(1):93.

22. Lawson JA, Janssen I, Bruner MW, Madani K, Pickett W. Urban-rural differences in asthma prevalence among young people in Canada: the roles of health behaviors and obesity. Annals of Allergy, Asthma and Immunology. 2011;107(3):220-8.

23. Jie $\mathrm{Y}$, Isa ZM, Jie $\mathrm{X}$, Ju ZL, Ismail $\mathrm{NH}$. Urban vs. rural factors that affect adult asthma. In Reviews of Environmental Contamination and Toxicology
Volume 2262013 (pp.33-63). Springer New York.

24. Salam MT, Islam T, Gilliland FD. Recent evidence for adverse effects of residential proximity to traffic sources on asthma. Current Opinion Pulmonary Med. 2008;14(1):3-8.

25. Gold DR, Wright R. Population disparities in asthma. Annu Rev Public Health. 2005;26:89-113.

26. Thomson NC, Spears M. The influence of smoking on the treatment response in patients with asthma. Current Opinion Allergy Clinical Immunol. 2005;5(1):57-63.

27. O'Rourke ST. Antianginal actions of beta-adrenoceptor antagonists. Am J Pharm Educ. 2007;71(5):95.

28. Lehmann, I, Rehwagen M, Diez U. Enhanced in vivo IgE production and $T$ cell polarization toward the type 2 phenotype in association with indoor exposure to VOC: results of the LARS study. Inter J Hygiene Enviro Health. 2001;204(4):211-21.

29. Oeie L, Hersoug LG, Madsen JO. Residential Exposure to Plasticizers and Its Possible Role in the Pathogenesis of Asthma. Environ Health Perspective. 1997;105(9):972-8.

30. Kanatani KT, Ito I, Al-Delaimy WK. Desert dust exposure is associated with increased risk of asthma hospitalization in children. American J Respiratory Critical Care Med. 2010;182(12):1475-81.

31. Rathore AW, Randhawa SM, Quratul Ain, Sajid M. Wheezing conditions in early childhood: prevalence and risk factors among pre-school children. Ann King Edward Med Coll. 2005;11(1):14-6.

32. Sim SW, Moey KSP, Tan NC. The use of facemasks to prevent respiratory infection: a literature review in the context of the Health Belief Model. Singapore Med J. 2014;55(3):160-7.

33. Rhee H, Belyea MJ, Brasch J. Family support and asthma outcomes in adolescents: barriers to adherence as a mediator. J Adolescent Health. 2010;47(5):472-8.

34. Kuo PC, Huang JH, Liu MD. Avian influenza risk perception and preventive behavior among traditional market workers and shoppers in Taiwan: practical implications for prevention PLoS One. 2011;6(9):e24157.

35. Taburet AM, Schmit B. Pharmacokinetic optimization of asthma treatment. Clinical Pharmacokinetics. 1994; 26(5):396-418.

36. Lavorini F, Levy ML, Dekhuijzen PNR, Crompton GK. On behalf of the ADMIT Working Group. Inhaler choice and inhalation technique: key factors for asthma control. Prim Care Respiratory J. 2009;18(4):241-2.

37. Giraud V, Roche N. Misuse of corticosteroid metered-dose inhaler is associated with decreased asthma stability. Euro Respiratory J .2002;19(2):246-51.

38. Goodman DE, Israel E, Rosenberg M, Johnston R, Weiss ST, Drazen JM. The influence of age, diagnosis, and gender on proper use of metereddose inhalers. Am J Respiratory Critical Care Med. 1994;150(5):1256-61.

Cite this article as: Hassan GA, Ahsan S, Asem M, Taha I, Muhammad U, Waqar SM, Abu-Bakar A, Cheng MW. Role and Frequency of Asthma Risk Factors in Triggering the Asthmatic Attack: A Cross-Sectional Study from Pakistan. J Pharm Pract Community Med. 2017;3(4):277-84. 